BUDGETING : Journal of Business, Management and Accounting

Volume 1, Nomor 2, Juni 2020

e-ISSN: $2715-2480$

p-ISSN: 2715-1913

DOI : https://doi.org/10.31539/budgeting.v1i2.795

\title{
ANALISIS STRUKTUR ASET DALAM MENGUKUR AKTIVITAS DAN PROFITABILITAS PERUSAHAAN
}

\author{
Gia Tamara Sukandi ${ }^{1}$, Nor Norisanti ${ }^{2}$, Acep Samsudin ${ }^{3}$ \\ Universitas Muhammadiyah Sukabumi ${ }^{1,2,3}$ \\ giatamara3@gmail.com ${ }^{1}$
}

\begin{abstract}
ABSTRAK
Penelitian ini bertujuan untuk mengetahui analisis struktur aset dalam mengukur aktivitas dan profitabilitas pada perusahan sub sektor peralatan rumah tangga yang terdaftar di BEI. Penelitian ini menggunakan metode deskriptif kuantitatif, data sekunder berupa laporan keuangan perusahaan sub sektor peralatan rumah tangga periode 2015 hingga 2017. Analisis yang digunakan yaitu analisis horizontal untuk mengukur struktur aset, perputaran piutang (RTO), perputaran persediaan (ITO), perputaran modal kerja (WCTO), perputaran aktiva tetap (FATO), perputaran total aset (TATO), pengembalian aset (ROA) dan menggunakan ratarata standar industri. Hasil penelitian menunjukan bahwa selama tiga periode PT. Integra Indocabinet Tbk mengalami peningkatan akan aktiva dan laba. Sedangkan PT. Chitose Internasional Tbk dan PT. Kedaung Indah Can Tbk mengalami flukturasi pada aktiva, dan adanya peningkatan pada laba. PT. Langgeng Makmur Industri Tbk menglami penurunan aktiva dan laba. Simpulan, perusahaan yang dikatakan baik adalah perusahaan yang melampaui rata-rata industri. Sedangkan perusahaan dengan nilai rendah disebabkan nilai yang diperoleh tidak selalu melampaui rata rata standar industri.
\end{abstract}

Kata Kunci : Aktivitas, Struktur Aset, dan Profitabilitas Perusahaan

\section{ABSTRACT}

This study aims to determine the analysis of asset structure in measuring the activity and profitability of the household appliances sub sector listed on the IDX. This study uses descriptive quantitative method, secondary data in the form of financial statements of household appliances sub-sector 2015 to 2017. The analysis used is horizontal analysis to measure asset structure, accounts receivable turnover (RTO), inventory turnover (ITO), working capital turnover ( WCTO), fixed asset turnover (FATO), total asset turnover (TATO), asset return (ROA) and using industry standard averages. The results showed that for three periods PT. Integra Indocabinet Tbk has increased its assets and profits. Whereas PT. Chitose Internasional Tbk and PT. Kedaung Indah Can Tbk experienced a fluctuation in assets, and an increase in profit. PT. Langgeng Makmur Industri Tbk experienced a decline in assets and profits. Conclusion, the company that is said to be good is a company that exceeds the industry average. While companies with low values are due to the value obtained does not always exceed the average industry standard.

Keywords: Activity, Asset Structure, and Company Profitability 


\section{PENDAHULUAN}

Pada umumnya suatu negara mengalami pertumbuhan ekonomi yang sangat dipengaruhi oleh para pengelola sebuah perusahaan yang sukses dalam menjalankan usahanya. Dalam memperlancar bisnis yang dijalankan, suatu perusahaan juga meningkatkan bisnis yang dikelolanya. Dalam mengembangkan usahanya, perusahaan melakukan suatu kegiatan dengan guna untuk mendapatkan suatu dana agar usaha yang dikelola berjalan dengan lancar.

Berdasarkan berita yang dilansir oleh www.bps.go.id, menyatakan bahwa perkembangan konsumsi rumah tangga Indonesia dapat dilihat dari angka pertumbuhan yang setiap tahunnya mengalami penaikan dan penurunan terhadap dana konsumsi masyarakat Indonesia terhadap peralatan rumah tangga. Dinilai pada tahun 2015 Indonesia mengalami pertumbuhan konsumsi rumah tangga sebesar 4,96\%. Pada tahun berikutnya yaitu tahun 2016 memiliki penaikan persentase sebesar $5,01 \%$, akan tetapi persentase tersebut mengalami penurunan 0,06\% pada tahun 2017. Nilai persentase yang diraih pada tahun 2017 diperoleh sebanyak $4,95 \%$.

Perusahaan diharuskan mengukur seberapa tingkat efisiensi perusahaan dalam memanfaatkan sumber daya perusahaan dalam melaksanakan aktivitas sehari-hari. Pengukuran yang dihasilkan oleh rasio aktivitas ini dapat mengukur apakah sebuah perusahaan lebih efisien atau sebaliknya dalam mengelola sebuah aset yang dimiliki sebuah perusahaan.

Perusahaan memerlukan sumber dana atau aset untuk menunjang pencapaian tujuan perusahaan dan keberlangsungan hidup usahanya. Pada hakekatnya struktur aset atau aktiva digunakan untuk membiayai operasi seharihati, baik dalam jangka pendek, jangka menengah maupun jangka panjang. Diharapkan setiap struktur aset atau dana yang dikeluarkan oleh perusahaan dapat kembali masuk dalam jangka waktu yang pendek melalui hasil penjualan produk atau barang, dan yang telah kembali akan digunakan untuk membiayai kegiatan operasi selanjutnya. Dengan demikian dana tersebut akan terus berputar selama perusahaan masih berjalan. 
Aktiva atau aset memiliki beberapa komposisi didalamnya. Aktiva tetap dalam perusahaan yang memiliki jumlah yang besar akan mempunyai sebuah peluang yang dimana untuk mendapatkan tambahan modal. Pada umumnya struktur aktiva atau aset ini ddiperuntukkan sebagai penetuan untuk alokasi dana, yang dimana seberapa besar alokasi dana untuk masing-masing komponen sebuah aktiva yang dimana terdapat aktiva lancar dan aktiva tetap. Maka tingkat nilai sebuah struktur aktiva perusahaan semakin tinggi, maka akan menunjukan bagaimana kemampuan sebuah perusahaan semakin tinggi maka perusahaan tersebut dapat menjamin sebuah kegiatan operasional sebuah perusahaan tersebut.

Struktur aktiva diambil dari konsep modal kerja yang memiliki keterkaitan satu sama lain. Konsep kualitatif yang dimana merupakan sebuah konsep dari modal kerja yang memiliki arti bahwa jumlah total dari aktiva. Dalam konsep ini bagaimana sebuah perusahaan dapat mencukupi kebutuhan dana yang untuk membiayai operasi dari sebuah perusahaan tersebut dalam jangka pendek.

Pengukuran struktur aset atau aktiva dalam mengukur profitabilitas tersebut dapat dijadikan dasar bagi manajemen perusahaan dalam melakukan pengendalian asetnya, rencana pembiayaan dan lain sebagainya. Adanya peningkatan laba atau profitabilitas akan mempermudah perusahaan untuk mengukur struktur aset atau aktiva. Oleh karena itu, dengan profitabilitas ini, pemilik perusahaan dapat bekerja secara efisien mungkin agar struktur aset atau aktiva yang dikeluarkan dapat terarah dan baik.

Penulisan tentang Struktur Aset dan Profitabilitas ini pernah dilakukan oleh Astuti dan Hotima (2016) yang menyatakan bahwa struktur aktiva berpengaruh terhadap profitabilitas. Pernyataan tersebut membuktikan bahwa struktur aset dapat mengukur profitabilitas perusahaan yang dimana dengan mengelola suatu aset dengan efisien dapat menghasilkan sebuah pendapatan atau laba yang diharapkan oleh perusahaan.

Dengan keadaan laporan keuangan pada laba bersih terdapat beberapa perusahaaan dalam setiap tahunnya mengalami penaikan laba. Beberapa perusahaan pun mengalami keadaan keuangan flukturatif yang dimana perusahaan belum bisa mendapatkan laba sesuai yang menjadi tujuan perusahaan. 
Berdasarkan uraian di atas terjadi permasalahan flukturasi pada aktivitas perusahaan dan perolehan laba. Maka dirasa penting untuk meneliti bagaimana struktur aset perusahaan Sub Sektor peralatan Rumah Tangga yang terdaftar di Bursa Efek Indonesia Tahun 2015-2017, maka penulis tertarik melakukan penelitian dengan judul "Analisis Struktur Aset Dalam Mengukur Aktivitas Dan Profitabilitas Pada Perusahaan Sub Sektor Peralatan Rumah Tangga Yang Terdapatar Di BEI". Tujuan penelitian ini adalah untuk mengetahui analisis struktur aset dalam mengukur aktivitas dan profitabilitas pada perusahan sub sektor peralatan rumah tangga yang terdaftar di BEI.

\section{KAJIAN TEORI}

\section{Struktur Aset}

Menurut Samsudin (2009) struktur aktiva diambil dari konsep modal kerja yang memiliki keterkaitan satu sama lain. Konsep kualitatif dimana merupakan sebuah konsep dari modal kerja yang memiliki arti bahwa jumlah total dari aktiva. Dalam konsep ini bagaimana sebuah perusahaan dapat mencukupi kebutuhan dana untuk membiayai operasi dari sebuah perusahaan tersebut dalam jangka pendek."

Dalam kegiatan ini, perusahaan diwajibkan untuk dapat melaksanakan tugas yang telah menjadi kewajibannya. Aktiva lancar dan aktiva tetap yang harus dikendalikan perusahaan akan aset yang dimiliki harus digunakan secara efisien guna untuk mewujudkan tujuan perusahaan kedepannya. Kemudian, hasil dari penggunaan aset secara baik menjadikan pedoman dalam perbaikan dalam pengefesiensikan struktur aset dengan baik.

Aktiva dibagi menjadi dua kelompok yaitu aktiva lancar dan aktiva tetap sebagai berikut:1) Aktiva Lancar (Current Assets), merupakan aktiva yang secara normal ditranformasikan menjadi kas dalam jangka waktu setahun atau sebelum berakhirnya siklus produksi (jika siklus ini melebihi jangka waktu setahun); 2) Aktiva Tetap (Fixed Assets), aktiva yang dipergunakan dalam perusahaan dan mempunyai kegunaan yang melebihi satu masa pembukuan. 


\section{Aktivitas}

Menurut Kasmir (2015) Rasio aktivitas merupakan rasio yang digunakan untuk mengukur efektivitas perusahaan dalam menggunakan aktiva yang dimilikinya dapat dikatakan pula rasio ini digunakan untuk mengukur tingkat efisiensi (efektivitas) pemanfaatan sumber daya perusahaan.

Menurut Hery (2015) jenis-jenis rasio aktivitas adalah berdasarkan sebagai berikut; 1) Perputaran piutang (receivable turn over), merupakanrasio yang mengukur piutang yang dimiliki oleh suatu perusahaan mempunyai hubungn yang erat dengan volume penjualan kredit; 2) Perputaran persediaan (inventory turnover), merupakan rasio yang mengukur kemampuan dana yang tertanam dalam inventory berputar dalam suatu periode tertentu, atau likuiditas dari inventory dan tendensi untuk adanya overstock; 3) Perputaran modal kerja (working capital turn over), merupakan perbandingan antara penjualan dengan modal kerja bersih; 4) Perputaran aktiva tetap (fixed assets turnover), merupakan rasio yang mengukur efektivitas penggunaan dana yang tertanam pada harta tetap; 5) Perputaran total aktiva ( total assets turn over), merupakan rasio yang menggambarkan kecepatan perputarannya total aktiva dalam satu periode tertentu.

\section{Profitabilitas}

Menurut Munawir (2010) Rentabilitas atau Profitabilitas menunjukkan kemampuan perusahaan untuk menghasilkan laba selama periode tertentu. Rasio profitabilitas memberikan jawaban akhir bagi manjemen perusahaan karena rasio profitabilitas ini memberikan gambaran mengenai efektifitas pengelolaan perusahaan. Dalam penelitian ini, rasio yang digunakan adalah Return On Assets (ROA).

Menuru Munawir (2010) dalam profitabilitas terdapat rasio Return On Assets (ROA), dapat diartikan Return On Assets (ROA) adalah "Rasio yang digunakan untuk mengukur kemampuan perusahaan mengasilkan laba dengan menggunakan total aktiva (kekayaan) yang dipunyai perusahan setelah disesuaikan dengan biaya-biaya untuk mendanai aset tersebut (Mamduh M. Hanafi dan Abdul Halim, 2014). 


\section{METODE PENELITIAN}

Metode penelitian yang digunakan adalah metode deskriptif. Dalam pengumpulan data yang digunakan adalah data sekunder, yang berupa dokumentasi-dokumentasi dan studi kepustakaan. Objek penelitian ini adalah perusahaan peralatan rumah tangga yang terdaftar di Bursa Efek Indonesia (BEI), yaitu perusahaan PT. Intergra Indocabinet Tbk (WOOD), PT. Chitose Internasional Tbk (CINT), PT. Kedaung Indah Can Tbk (KICI) dan PT. Langgeng Makmur Industri Tbk (LMPI). Teknik anlisis data yang digunakan dalam penelitian ini adalah analisis vertikal yang digunakan untuk menganalisis struktur aset perusahaan yang diukur dari rasio aktivitas yaitu, receivable turn over, inventory turn over, working capital turn over, total assets turn over dan fixed assets turn over. Serta rasio profitabilitas yaitu return on assets (ROA).

\section{Tabel 1.}

Operasionalisasi Konsep

\begin{tabular}{|c|c|c|c|}
\hline Variabel & Dimensi & Indikator & Konsep \\
\hline Struktur Aset & Neraca & $\begin{array}{ll}\text { - } & \text { Aktiva lancar } \\
\text { - } & \text { Total Aktiva } \\
\text { - } & \text { Aktiva Tetap } \\
\text { - } & \text { Total Aktiva }\end{array}$ & $\begin{array}{l}\text { Perbandingan antara aktiva } \\
\text { lancar dengan total aktiva } \\
\text { yang ada. } \\
\text { Membandingkan antara } \\
\text { aktiva tetap dengan total } \\
\text { aktiva yang ada dalam } \\
\text { perusahaan. }\end{array}$ \\
\hline \multirow[t]{5}{*}{ Aktivitas } & $\begin{array}{lr}\text { Perputaran } & \text { Piutang } \\
\text { (Receivalbe } & \text { Turn } \\
\text { Over) } & \\
\end{array}$ & $\begin{array}{ll}\text { - } & \text { Penjualan } \\
\text { - } & \text { Piutang }\end{array}$ & $\begin{array}{lr}\text { Perbandingan } & \text { antara } \\
\text { penjualan dengan piutang } \\
\text { perusahaan. }\end{array}$ \\
\hline & $\begin{array}{l}\text { Perputaran Persediaan } \\
\text { (Inventory Turn Over) }\end{array}$ & $\begin{array}{ll}\text { - } & \text { Penjualan } \\
\text { - } & \text { Persediaan }\end{array}$ & 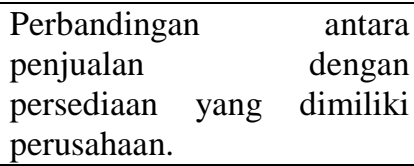 \\
\hline & $\begin{array}{lr}\text { Perputaran } & \text { Modal } \\
\text { Kerja } & \text { (Working } \\
\text { Capital Turn } & \text { Over) }\end{array}$ & $\begin{array}{ll}\text { - } & \text { Penjualan } \\
\text { - } & \text { Rata-rata Aset }\end{array}$ & $\begin{array}{l}\text { Rasio perbandingan antara } \\
\text { penjualan dengan rata-rata } \\
\text { aset dalam perusahaan. }\end{array}$ \\
\hline & $\begin{array}{l}\text { Total Assets Tur Over } \\
\text { (TATO) }\end{array}$ & $\begin{array}{ll}\text { - } & \text { Penjualan } \\
\text { - } & \text { Aktiva Tetap }\end{array}$ & $\begin{array}{ll}\text { Perbandingan } & \text { antara } \\
\text { penjualan dengan } & \text { aktiva } \\
\text { tetap yang ada. } & \end{array}$ \\
\hline & $\begin{array}{l}\text { Fixed Assets Turn } \\
\text { Over (FATO) }\end{array}$ & $\begin{array}{ll}\text { - } & \text { Penjualan } \\
\text { - } & \text { Total Aktiva }\end{array}$ & $\begin{array}{l}\text { Membandingan antara } \\
\text { penjualan dan total aktiva } \\
\text { yang ada dalam perusahaan. }\end{array}$ \\
\hline Profitabilitas & $\begin{array}{l}\text { Return On Assets } \\
(\text { ROA })\end{array}$ & $\begin{array}{lr}\text { - } & \text { Laba Bersih } \\
\text { Setelah Pajak } \\
\text { - } \quad \text { Total Aktiva }\end{array}$ & $\begin{array}{l}\text { Membandingkan laba bersih } \\
\text { setelah pajak dengan total } \\
\text { aktiva yang ada. }\end{array}$ \\
\hline
\end{tabular}




\section{HASIL PENELITIAN}

Berdasarkan data yang telah dikeluarkan oleh PT. Intergra Indocabinet Tbk (WOOD), PT. Chitose Internasional Tbk (CINT), PT. Kedaung Indah Can Tbk (KICI) dan PT. Langgeng Makmur Industri Tbk (LMPI) melalui Bursa Efek Indonesia berupa data laporan-laporan keuangan periode 2015-2017 yang diperuntukan bagi pemegang saham dan bagi pihak-pihak berkpentingan dengan laporan tersebut.

Tabel 2.

Rata-Rata Industri Receivable Turn Over Ratio

Perusahahaan Sub Sektor Peralatan Rumah Tangga Periode 2015-2017

\begin{tabular}{cllll}
\hline No. & Nama Perusahaan & $\mathbf{2 0 1 5}$ & $\mathbf{2 0 1 6}$ & $\mathbf{2 0 1 7}$ \\
\hline 1. & PT. Integra Indocabinet Tbk & 10,83 & 29,89 & 45,89 \\
2. & PT. Chitose Internasional Tbk & 6,28 & 5,36 & 9,89 \\
3. & PT. Kedaung Indah Can Tbk & 10 & 5,72 & 8,28 \\
4. & PT. Langgeng Makmur Industri Tbk & 1,76 & 1,59 & 1,73 \\
Total & & 28,87 & 42,56 & 65,79 \\
Rata-Rata & $7,2 \mathrm{kali}$ & $10,6 \mathrm{kali}$ & $16,5 \mathrm{kali}$ \\
\hline
\end{tabular}

Sumber: Laporan keuangan, data diolah 2019

Berdasarkan tabel diatas, bahwa pada tahun 2015 memiliki rata-rata industri perusahaan sub sektor perusahaan peralatan dan rumah tangga untuk Receivable Turn Over ini adalah 7,2 kali. Dengan daripada itu, PT. Integra Indocabinet Tbk merupakan perusahaan dengan kinerja keuangan yang baik, dan dapat melampaui dari rata-rat industri. Hasil yang dapat dikatakan bahwa perusahaan ini memiliki dana yang tertanam dalam persediaan yang berputar dalam satu periode dengan baik. Sedangkan PT. Chitose Internasional Tbk, PT. Kedaung Indah Can Tbk dan PT. Langgeng Makmur Indurstri Tbk merupakan perusahaan-perusahaan yang tidak mampu melewati rata-rata industri yang ada, dan perusahaan tersebut dinilai kurang baik dalam kinerja keuangannya.

Selanjutnya nilai rata-rata industri pada tahun 2016 memiliki nilai sebesar 10,6 kali. Pada nilai rata-rata industri ini pun PT. Integra Indocabinet Tbk memilki nilai diatas rata-rata industri sebesar 29,89 kali yang dimana dapat dikatakan jauh dari rata-rata industi yang bersifat sangat baik bagi perusahaan. Yang dapat mengolah dana yang tertanam dalam persediaan tersebut baik, dan memiliki keuntungan baik bagi perusahaan dalam menjalankan kegiatan usahanya. Sedangkan PT. Chitose Internasional Tbk, PT. Kedaung Indah Can Tbk 
dan PT. Langgeng Makmur Indurstri Tbk merupakan perusahaan-perusahaan yang tidak mampu melewati rata-rata industri yang ada, dan perusahaan tersebut dinilai kurang baik dan berakibat bagi kegiatan operasional perusahaan.

Pada tahun 2017 rata-rata industri unutk receivable turn over memiliki nilai 16,5 kali. Pada tahun 2017 T. Integra Indocabinet Tbk memilki nilai diatas rata-rata industri sebesar 45,89 kali. Nilai tersebut dapat dilihat dari 3 periode dari tahun 2015 hingga 2017 PT. Integra Indocabinet mengalami kenaikan drastic. Kenaikan tersebut berdampak bagi perusahaan tersebut, karena dapat mengukur berapa kali dana yang yag telah berputar dalam satu periode. Berbanding terbalik dengan PT. Chitose Internasional Tbk, PT. Kedaung Indah Can Tbk dan PT. Langgeng Makmur Indurstri Tbk dari tahun ketahun mengalami penurunan, yang berakbat bagi kinerja keuangan perusahaan yang tidak baik dan berdampak bagi perusahaan.

Tabel 3.

Rata-Rata Industri Inventory Turn Over Ratio

Perusahahaan Sub Sektor Peralatan Rumah Tangga Periode 2015-2017

\begin{tabular}{cllll}
\hline No. & Nama Perusahaan & $\mathbf{2 0 1 5}$ & $\mathbf{2 0 1 6}$ & $\mathbf{2 0 1 7}$ \\
\hline 1. & PT. Integra Indocabinet Tbk & 4,95 & 15,63 & 4,43 \\
2. & PT. Chitose Internasional Tbk & 1,39 & 4,22 & 0,95 \\
3. & PT. Kedaung Indah Can Tbk & 0,4 & 1,17 & 0,29 \\
4. & PT. Langgeng Makmur Industri Tbk & 2 & 4,87 & 1,05 \\
& $\quad$ Total & 8,74 & 25,89 & 7,17 \\
& Rata-Rata & $2,2 \mathrm{kali}$ & $6,5 \mathrm{kali}$ & $1,8 \mathrm{kali}$ \\
\hline
\end{tabular}

Sumber: Laporan keuangan, data diolah 2019

Berdasarkan tabel diatas, bahwa pada tahun 2015 memiliki rata-rata industri perusahaan sub sektor perusahaan peralatan dan rumah tangga untuk Inventory Turn Over ini adalah 8,74 kali. Dengan daripada itu, PT. Integra Indocabinet Tbk merupakan perusahaan dengan kinerja keuangan yang baik, kearena perusahaan ini lebih efektif dalam melakukan kegiatan operasional perusahaan. Sedangkan PT. Chitose Internasional Tbk, PT. Kedaung Indah Can Tbk dan PT. Langgeng Makmur Indurstri Tbk merupakan perusahaan-perusahaan yang tidak mampu melewati rata-rata industri yang ada, dan perusahaan tersebut dinilai memiliki kondisi kurang baik. 
Selanjutnya nilai rata-rata industri pada tahun 2016 memiliki nilai sebesar 6,5 kali. Pada nilai rata-rata industri ini pun PT. Integra Indocabinet Tbk mengayang baik bagi perusahaan dengan angka 15,63. Ini merupakan pencapaian yang sangat baik bagi perusahaan. Akan tetapi, pada tahun ini pula ke 3 perusahaan yang sama pada tahun sebelumnya tidak mengalami keadaaan yang baik.

Pada tahun 2017 rata-rata industri unutk Inventory Turn Over memiliki nilai 1,8 kali. Pada tahun ini PT. Integra Indocabinet Tbk memilki nilai diatas rata-rata industri kembali sebesar 4,4 kali. Berbanding terbalik dengan PT. Chitose Internasional Tbk, PT. Kedaung Indah Can Tbk dan PT. Langgeng Makmur Indurstri Tbk masing-masing dari perusahaan ini tidak mengalami peningkatan dalam penjualannya, dan dapat dikatakan bahwa perusahaanperusahan tersebut cenderung tidak baik dalam mengolah penjualan persediaan perusahaan tersebut.

Tabel 4.

Rata-Rata Industri Working Capital Turn Over Ratio

Perusahahaan Sub Sektor Peralatan Rumah Tangga Periode 2015-2017

\begin{tabular}{cllll}
\hline No. & Nama Perusahaan & $\mathbf{2 0 1 5}$ & $\mathbf{2 0 1 6}$ & $\mathbf{2 0 1 7}$ \\
\hline 1. & PT. Integra Indocabinet Tbk & 2,46 & 2,46 & 2,73 \\
2. & PT. Chitose Internasional Tbk & 0,69 & 0,6 & 0,59 \\
3. & PT. Kedaung Indah Can Tbk & 0,2 & 0,18 & 0,18 \\
4. & PT. Langgeng Makmur Industri Tbk & 0,99 & 0,77 & 0,65 \\
& $\quad$ Total & 4,34 & 4,01 & 4,15 \\
& $\quad$ Rata-Rata & 1,08 kali & 1 kali & 1,04 kali \\
\hline
\end{tabular}

Sumber: Laporan keuangan, data diolah 2019

Berdasarkan tabel diatas, bahwa pada tahun 2015 hasil perhitungan Working Capital Turn Over memiliki rata-rata industri sebsar 1,08 kali. Dapapt dilihat dari perusahaan-perusahaan diatas tersebut yang mengalami penaikan akan perputaran modal kerja secara efektif adalah PT. Integra Indocabiner Tbk. Sedangkan PT. Chitose Internasional tidak mengalami kenaikan akan perputaran modal kerja yang dimiliki perusahaanya. Sama hal nya dengan PT. Kedaung Indah can Tbk dan PT. Langgeng Makimur Industri Tbk tidak melngami kenaikan pada perputaran modal kerja yang tidak baik bagi perusahaan. 
Selanjutnya nilai rata-rata industri pada tahun 2016 memiliki nilai sebesar 1 kali. Pada nilai rata-rata industri ini pun PT. Integra Indocabinet Tbk sebesar 2,46 kali yang dimana dapat disimpulkan bahwa kontribusi aset lancar terhadap penjualan cenderung baik. mengayang baik bagi perusahaan dengan angka 15,63. Ini merupakan pencapaian yang sangat baik bagi perusahaan. Akan tetapi, pada tahun ini pula ke 3 perusahaan yang sama pada tahun sebelumnya tidak mengalami keadaaan yang baik. Berbanding terbalik dengan PT. Chitose Internasional Tbk, PT. Kedaung Indah Can Tbk dan PT. Langgeng Makmur Indurstri Tbk yang tidak efektif mengolah modal kerja yang dimiiki dalam mengasilkan penjualan. Oleh karena itu, perusahaan-perusahaan tersebut cenderung kurang efektif dalam mengolah modal kerjannya akan menghasilkan penjualan perusahaannya.

Pada tahun 2017 rata-rata memiliki nilai 1,04 kali. Pada tahun ini PT. Integra Indocabinet Tbk memilki nilai diatas rata-rata industri kembali sebesar 2,73 kali. Berbanding terbalik dengan PT. Chitose Internasional Tbk, PT. Kedaung Indah Can Tbk dan PT. Langgeng Makmur Indurstri Tbk masingmasing dari perusahaan ini tidak mengalami peningkatan karena kurang efektifnya dalam mengolah modal kerjannya akan menghasilkan penjualan perusahaannya.

Tabel 5.

Rata-Rata Industri Total Assets Turn Over Ratio Perusahahaan Sub Sektor Peralatan Rumah Tangga Periode 2015-2017

\begin{tabular}{lllll}
\hline No. & Nama Perusahaan & 2015 & 2016 & 2017 \\
\hline 1. & PT. Integra Indocabinet Tbk & 0,55 & 0,43 & 0,45 \\
2. & PT. Chitose Internasional Tbk & 0,82 & 0,82 & 0,78 \\
3. & PT. Kedaung Indah Can Tbk & 0,68 & 0,71 & 0,76 \\
4. & PT. Langgeng Makmur Industri Tbk & 0,57 & 0,51 & 0,49 \\
& $\quad$ Total & 2,62 & 2,47 & 2,48 \\
& $\quad$ Rata-Rata & $0,65 \mathrm{kali}$ & $0,62 \mathrm{kali}$ & $0,62 \mathrm{kali}$ \\
\hline
\end{tabular}

Sumber: Laporan keuangan, data diolah 2019

Berdasarkan tabel diatas, bahwa pada tahun 2015 memiliki rata-rata industri perusahaan sub sektor perusahaan peralatan dan rumah tangga untuk Total Assets Turn Over ini adalah 7,2 kali. Dengan daripada itu, PT. Integra Indocabinet Tbk dan Kedaung Indah Can Tbk merupakan perusahaan dengan kinerja keuangan yang baik, dan dapat melampaui dari rata-rat industri. Dapat 
disimpulkan bahwa kontribusi total aset terhadap penjualan perusahaan tersebut cenderung baik. Sedangkan perusahaan-perusahan yang menunjukan kinerja keuangan yang kurang baik adalah PT. Chitose Internasional Tbk dan PT. Langgeng Makmur Indurstri Tbk.

Nilai rata-rata industri 2016 memiliki nilai sebesar 0,62kali. Dapat dilihat bahwa pada tahun 2016 yang memiliki kinerja keuangan akan total asetnya yang baik adalah PT. Chitose Internasional Tbk, PT. Kedaung Indah Can Tbk, karena perusahaan tersebut telah melampaui dari rata-rata industri untuk Total Assets Turn Over pada tahun 2016. Akan tetapi pada PT. Integra Indocabinet Tbk dan Langgeng Makmur Indurstri Tbk merupakan perusahaan-perusahaan yang tidak mampu melewati rata-rata industri yang ada, dan perusahaan tersebut dinilai kurang baik karena mengalami kinerja keuangan yang kurang baik.

Pada tahun 2017 rata-rata industri unutk Total Assets Turn Over memiliki nilai 0,62 kali. Pada tahun 2017 PT.Chitose Internasional Tbk dan PT. Kedaung Indah Can Tbk memiliki kinerja keuangan yang baik. Sedangkan pada PT. Integra Indocabinet Tbk dan Langgeng Makmur Indurstri rbanding terbalik, karena cenderung memilki kinerja keuangan yang kurang baik.

Tabel 6.

Rata-Rata Industri Fixed Assets Turn Over Ratio

Perusahahaan Sub Sektor Peralatan Rumah Tangga Periode 2015-2017

\begin{tabular}{lllll}
\hline No. & Nama Perusahaan & 2015 & 2016 & 2017 \\
\hline 1. & PT. Integra Indocabinet Tbk & 0,57 & 0,8 & 1,03 \\
2. & PT. Chitose Internasional Tbk & 1,98 & 1,8 & 1,59 \\
3. & PT. Kedaung Indah Can Tbk & 1,87 & 2,13 & 0,76 \\
4. & PT. Langgeng Makmur Industri Tbk & 1,73 & 1,14 & 0,49 \\
& $\quad$ Total & 6,15 & 5,87 & 3,87 \\
& $\quad$ Rata-Rata & 1,54 kali & 1,47 kali & 0,97 kali \\
\hline
\end{tabular}

Sumber: Laporan keuangan, data diolah 2019

Berdasarkan tabel diatas, bahwa pada tahun 2015 memiliki rata-rata industri ini adalah 1,54 kali. Perusahaan-perusahaan yang mengalami kenaikan akan kinerja keuangan dengan baik dan dalam keefektifan menggunakan aset tetap yang dimiliki perusahaan dalam menghasilkan penjualan adalah PT. Chitose Internasional Tbk, PT. Kedaung Indah Can Tbk dan PT. Langgeng Makmur Indurstri Tbk. Akan tetapi PT. Integra Indocabinet Tbk mengalami kondisi kurang 
baik dalam kinerja keuangan yang masi kurang efektif dalam mengolah aset tetap yang dimiliki perusahaan untuk menghasilkan penjualan.

Nilai rata-rata industri 2016 memiliki nilai sebesar 1,47 kali. Perusahaan yang mengalami kondisi kinerja keuanganyang baik adalah PT. Chitose Internasional Tbk, PT. Kedaung Indah Can Tbk, karena perusahaan tersebut dapat melampaui rata-rata industri. Akan tetapi pada PT. Integra Indocabinet Tbk dan PT. Langgeng Makmur Indurstri Tbk dapat dikatakan terjadinya penurunan dalam kinerja keuangan yang akan berdampak pada perusahaan.

Pada tahun 2017 rata-rata industri unutk Fixed Assets Turn Over memiliki nilai 0,97 kali. Perusahaan yang mengalami kinerja keuangan yang baik adalah PT. Integra Indocabinet Tbk dan PT.Chitose Internasional Tbk, karena kontribusi aset tetap terhadap penjualan perusahaan tersebut dikatakan baik, karena perusahaan tersebut dapat memanfaatkan perputaran aset tetap dengan baik. Akan tetapi hal yang terjadi pada PT. Kedaung Indah Can Tbk dan PT. Langgeng Makmur Indurstri Tbk dapat dikatakan cenderung kurang baik.

Tabel 7.

Rata-Rata Industri Return On Assets Ratio Perusahahaan Sub Sektor Peralatan Rumah Tangga Periode 2015-2017

\begin{tabular}{lllll}
\hline No. & Nama Perusahaan & 2015 & 2016 & 2017 \\
\hline 1. & PT. Integra Indocabinet Tbk & $1,18 \%$ & $4,58 \%$ & $4,46 \%$ \\
2. & PT. Chitose Internasional Tbk & $7,7 \%$ & $5,16 \%$ & $6,22 \%$ \\
3. & PT. Kedaung Indah Can Tbk & $9,71 \%$ & $0,26 \%$ & $5,32 \%$ \\
4. & PT. Langgeng Makmur Industri Tbk & $0,5 \%$ & $0,85 \%$ & $3,73 \%$ \\
& $\quad$ Total & $19,09 \%$ & $10,85 \%$ & $19,73 \%$ \\
& Rata-Rata & $4,77 \%$ & $2,71 \%$ & $4,93 \%$ \\
\hline
\end{tabular}

Sumber: Laporan keuangan, data diolah 2019

Berdasarkan tabel diatas, bahwa pada tahun 2015 memiliki rata-rata industri ini adalah 4,77\%. Perusahaan-perusahaan yang mengalami kenaikan akan kinerja keuangan dengan baik dan kemampuan perusahaan dalam menghasilkan laba adalah PT. Chitose Internasional Tbk, PT. Kedaung Indah Can Tbk. Akan tetapi PT. Integra Indocabinet Tbk dan PT. Langgeng Makmur Indurstri Tbk cenderung memiliki kinerja keuangan yang kurang baik, karena dalam kemampuan perusahan dalam menghasilkan laba masih belum maksimal. 
Nilai rata-rata industri 2016 memiliki nilai sebesar 2,71\%. Perusahaan yang mengalami kondisi kinerja keuangan yang baik dan perusahaan-perusahaan tersbut dapat memaksimalkan total aset dalam menghasilkan laba dengan baik adalah PT. Integra Indocabinet Tbk dan PT. Chitose Internasional Tbk. Berbanding terbalik dengan PT. Kedaung Indah Can Tbk dan PT. Langgeng Makmur Indurstri Tbk belum mampunya mengahsilkan laba dengan baik dengan menggunakan aset perusahaan yang ada.

Pada tahun 2017 rata-rata industri unutk Return On Asssets memiliki nilai 4,93\%. Perusahaan yang melampaui rata-rata industri adalah PT. Integra Indocabinet Tbk, PT.Chitose Internasional Tbk dan PT. Kedaung Indah Can Tbk. Karena perusahaan-perusahaan tersebut dapat memanfaatkan total aset yang dimiliki perusahaan dalam menghasilkan laba dengan baik. Akan tetapi berbanding terbalik PT. Langgeng Makmur Indurstri Tbk cederung memiliki kinerja keuangan yang kurang baik yang berdampak pada penghasilan laba yang diperoleh perusahaan.

\section{PEMBAHASAN}

\section{Analisis Struktur Aset Dalam Mengukur Aktivitas dan Profitabilitas Pada Perusahaan Sub Sektor Peralatan Rumah Tangga Yang Terdaftar Di BEI}

Berikut ini adalah analisis struktur aset yang diukur melalui rasio aktivitas dan rasio profitabilitas pada perusahaan sub sektor peralatan rumah tangga selama 3 tahaun, yang terhitung dari tahun 2015 hingga 2017. Berdasarkan data dan perhitungan rata-rata industri pada rasio aktivitas dan rasio profitabilitas yang dijadikan sebagai alat ukur untuk dapat menganalisis struktur aset.

Terhitung pda tahun 2015 hingga 2017 perusahaan yang memperoleh nilai diatas rata-rata industri adalah PT. Integra Indocabinet Tbk. Hal ini menandakan bahwa perusahaan tersebut memiliki struktur aset yang baik dan digunakan secara maksimal karena hasil dari perolehan yang didapatkan diatas rata-rata industri.penetapan perimbangan antara laba bersih dan total aktiva yang digunakan sangat berkesinambungan, karena dalam pemanfaatan total aktiva secara maksimal dan baik, pengahasilan laba yang diperoleh pun dinyatakan baik 
bagi perusahaan, karena dampak positif yang diterima perusahaan dapat menyebabkan kegiatan operasional perusahaan dalam menjalankan kegiatannya dengan baik.

Perusahaan sub sektor peralatan rumah tangga yang terdaftar di BEI yang selalu memiliki nilai yang jauh dibawah rata-rata industri adalah PT. Langgeng Makmur Industi Tbk. Hal ini menandakan bahwa perusahaan tersebut belum dapat memanfatkan total aktiva dengan baik, Karena hal tersebut akan berdampak pada penghasilan laba yang diperoleh perusahaan, dan kegiatan operasioanl perusahaan.

\section{SIMPULAN}

Perusahaan sub sektor peralatan rumah tangga yang terdaftar di BEI pada periode 2015 hingga 2017 diantaranya yaitu PT. Integra Indocabinet Tbk mengalami peningkatan pada perhitungan Receivable Turn Over Ratio, Working Capital Turn Over dan Fixed Assets Turn Over.dan mengalami keadaan flukturatif pada perhitungan Inventory Turn Over, Total Assets Turn Over dan Return On Assets.pada PT. Chitose Internasional Tbk mengalami flukturatif pada Receivable Turn Over ratio, Inventory Turn Over Ratio dan Retun On Assets danmengalami penurunan pada perhitungan Working Capital Turn Over Ratio, Total Assets Tun Over Ratiodan Fixed Assets Ratio.

PT. Kedaung Indah Can Tbk mengalami keadaan flukturatif pada perhitungan Receivable Turn Over Ratio, Inventory Turn Over Ratio, Working Capital Turn Over,Fixed Assets Turn Over Ratiodan Return On Asset, dan mengalami penaikan pada Total Assets Turn Over Ratio. Selanjutnya PT. Langgeng Makmur Industri Tbk mengalami flukturatif rata-raat industri pada perhitungan Receivable Turn Over Ratio, Inventory Turn Over Ratio,Fixed Assets Turn Over Ratio dan Return On Assets Ratio, dan mengalami penurunan pada perhitungan Working Capital Turn Over, Total Assets Turn Over Ratio. Akan tetapi perusahaan ini mengalami kenaikan pada perhitungan Return On Aseets Ratio. Perusahaan yang dikatakan baik adalah perusahaan yang melampaui rata- 
rata industri. Sedangkan perusahaan dengan nilai rendah disebabkan nilai yang diperoleh tidak selalu melampaui rata rata standar industri

\section{DAFTAR PUSTAKA}

Hanafi M. M \& Abdul, H. (2014). Analisis Laporan Keuangan. Yogyakarta:UPP STIM YKPN

Hery.(2015). Analisis Laporan Keuangan. Yogyakarta: CAPS

Kasmir. M.,M. (2015). Analisis Laporan keuangan. Jakarta: PT. Raja Grafindo

Munawir, S. (2010). Analisis Laporan Keuangan Edisi Kempat. Cetakan Kelima

Belas. Yogyakarta: Liberty

Samsuddin, L. (2011). Managemen Keuangan Perusahaan. Rajawali Pers

Astuti \& Hotima. (2016). Variabel yang Mempengaruhi Struktur Modal dengan Profitabilitas sebagai Variabel Intervening (Studi pada Industri Manufaktur di Bursa Efek Indonesia). UNEJ e-Proceeding, 398-413. 